\title{
The Political Economy of the Belarusian Crisis
}

Adam Przeworski famously wrote that "authoritarian equilibrium rests ... on lies, fear, or economic prosperity." Belarusian dictator Alexander Lukashenko has felt safe for his first twenty years in office primarily due to a strong economic performance. At the time of the previous presidential election in 2015, Belarusian GDP per capita (in purchasing power parity adjusted terms) was almost three times as high as in 1994 - the year when he came to power. On average, in 1994-2014, per capita incomes have been growing at a healthy 5.5\% annually. The catch, of course, was that this growth was due to massive subsidies from Russia: $10 \%-20 \%$ of GDP per year, by International Monetary Fund (IMF) estimates. Once the Russian economy went into a recession followed by prolonged stagnation due to a decline in oil prices and Western sanctions, Belarusian economic growth also ran out of steam. Russia went through a major austerity exercise at home and could not afford to be as generous to friendly authoritarian regimes as before. As a result, Belarusian GDP per capita stopped growing: its average annual growth rate in 2014-2019 was precisely zero.

Given the bankruptcy of Lukashenko's growth model, it is not surprising that he lost the 2020 election and resorted to violence and lies (for the latter he even had to import two planeloads of Russian TV propagandists). It is difficult at present to predict the outcome of his fight against Belarusian society. However, it is useful to discuss the structure of the Belarusian economy as this helps understand the country's political economy and thus inform Europe's strategy regarding Belarus.

First and foremost, the Belarusian economy is dominated by state-owned enterprises (SOEs) and state-owned banks. Despite many promises to both Russia and the West, Lukashenko has eschewed privatisation, so the share of the state in the Belarusian economy (and especially in its industry) is much higher than even in China. According to various estimates, SOEs account for half the GDP and almost $60 \%$ of employment. Some Belarusian SOEs are profitable but most are not and therefore rely on subsidised inputs from Russia or bailouts by state-owned banks. Much of the SOEs' debt to the banks or the markets will have to be assumed by the government or restructured, which in turn will mean that the banks will have to be bailed out by the government. However, the government's own debt is already growing quickly and further market borrowing is costly: Belarusian eurobonds trade at $7 \%$ per year in dollar terms.

The SOE subsidies are not only a fiscal problem; they also limit the chances of restarting economic growth. As SOEs depend on subsidies and bailouts, they have no incentive to restructure and invest efficiently and their productivity stagnates.

While SOEs dominate the commanding heights of the Belarusian economy, there is also a private sector - mostly small and medium-sized enterprises (SME). The private firms face an unfair competitive environment and are harassed by bureaucrats; those that survive are run by highly motivated and talented entrepreneurs. The private sector includes a very important enclave of IT companies - the High Technology Park (HTP). HTP is a special tax and legal regime which is used by more than 800 companies throughout the country. While they employ about $1 \%$ of Belarus' labour force, they account for about $10 \%$ of the country's exports. Lukashenko has always tried to take credit for the success of HTP. However, by 2020 it became clear that his

(C) The Author(s) 2020. Open Access: This article is distributed under the terms of the Creative Commons Attribution 4.0 International License (https://creativecommons.org/licenses/by/4.0/).

Open Access funding provided by ZBW - Leibniz Information Centre for Economics.

1 Przeworski, A. (1991), Democracy and the Market: Political and Economic Reforms in Eastern Europe and Latin America, 58, Cambridge University Press. 
outdated regime is a liability rather than an asset for the IT companies' further growth. HTP's falling out with Lukashenko is epitomised by HTP founder Valery Tsepkalo's bid for the presidential nomination in the 2020 elections. Tsepkalo was not registered as a candidate, was harassed by Lukashenko's 'law-and-order' agencies and was forced to emigrate.

Another important economic and political factor is the large diaspora. Various estimates suggest that 3.5 million Belarusians live outside the country - compared to about 9.5 million residing inside. The diaspora sends back remittances and promotes economic and social interactions between Belarus and other countries.

Given the economic dead end of the last few years, it is not surprising that private entrepreneurs and their employees - as well as Belarusians based abroad - saw the need for change. What was more striking is that they were supported by many SOE workers - previously, the stronghold of the regime. The likely explanation for this turnaround is the rise of social media that overcame the propaganda of state TV. Another opposition politician who attempted a presidential run this year, Sergei Tikhanovsky, rose to prominence through his YouTube blog. The blog has 300,000 subscribers and the most popular videos have been viewed over a million times. (Mr. Tikhanovsky was also unable to register as a presidential candidate; he was arrested before the election; however, his wife, Svetlana Tikhanovskaya, ran for president and apparently won the election in the first round). Since August, the main opposition Telegram channel, NEXTA, has grown to two million subscribers. The independent online media have probably convinced the state sector workers that Lukashenko's economic model is struggling - especially compared to already rich and growing European neighbors Poland and Lithuania.

The economic challenges are an important piece of the Belarusian puzzle. In order to continue paying his policemen, Lukashenko needs money. He also needs to roll over his external debt. In September 2020, Moody's warned that the Belarusian banking system faces major risks - and that the Central Bank's foreign currency reserves can only cover $25 \%$ of the banking system's foreign currency liabilities. Economic problems have also contributed to the downward pressure on the Belarusian ruble - which has lost a quarter of its value to the euro in the last 12 months.

This brings in the last missing piece of the Belarusian political economy: Russia. As it has done before, Russia could bail Belarus out. Not surprisingly, facing the protests and the growing economic difficulties, Mr. Lukashenko has intensified his contact with Vladimir Putin and has already announced that Russia is ready to help. Whether this is actually the case, and if so, what price Belarus would pay for a Russian bailout remains to be seen. In 2018-2019, Mr. Putin allegedly considered the "integration" of Belarus into Russia as a solution for his 2024 problem: creating a new state would allow him reset his term limits. As this scenario was blocked by Lukashenko then, Putin went for another, blunter approach simply rewriting the Russian Constitution and "zeroing out" term limits for himself. It is not impossible, however, to see that he still wants to return to the unification of Russia and Belarus. But losing national sovereignty would certainly be highly unpopular among Belarusians - and the Kremlin seems to understand this. Thus, it is not clear what Belarus strategy the Kremlin will choose.

What can the EU do? It has both principles and instruments to defend them. As it has done in the past, the EU should state clearly that stealing elections, arresting opposition politicians and beating peaceful protesters is wrong - and follow up with sanctions, putting the money where its mouth is. The EU should also promise economic support to the democratic and reform-oriented Belarus - both through the European Commission's toolkit and via the EU's and its allies' representation in international financial institutions such as the IMF, the World Bank and the European Bank for Reconstruction and Development. If Belarus embarks on the reform trajectory, there are many reasons to be optimistic about its economic performance. This is a well-educated country next to Europe. It does not have oligarchs and petty corruption. Finally, as the last weeks have demonstrated, its society wants to build a modern country based on European values.

Sergei Guriev, Sciences Po, Paris, France. 